\title{
Influence of the surface water quality of the Caño Correa on the coral reefs of the Corales del Rosario and San Bernardo National Natural Park (Colombian Caribbean)
}

\author{
Ildefonso Baldiris-Navarro ${ }^{\# 1}$, Jorge Sanchez-Aponte* ${ }^{2}$, Juan Acosta-Jimenez ${ }^{\# 3}$, \\ Carlos Severiche-Sierra ${ }^{\# \Phi 4}$, Rafael Correa-Turizo ${ }^{\# 5}$ \\ \#Technological University Foundation Comfenalco. Process Research Center of the Technological Comfenalco \\ - CIPTEC. Cartagena de indias, Bolivar, Colombia. \\ 1ibaldiris@tecnocomfenalco.edu.co \\ 3jcacosta@tecnologicocomfenalco.edu.co \\ ${ }^{4}$ cseveriche@tecnocomfenalco.edu.co \\ ${ }^{5}$ rcorreat@tecnocomfenalco.edu.co \\ *National Learning Service SENA. SENA CINAFLUP Research Group. Cartagena de indias, \\ Bolivar, Colombia. \\ 2ijsancheza@sena.edu.co \\ ФUniversidad de Cartagena. MAAS Research Group. Cartagena de indias, Bolivar, Colombia. \\ ${ }^{4}$ cseveriches@gmail.com
}

\begin{abstract}
The quality of the surface water of Caño Correa and its influence on the coral reefs of the Corales del Rosario and San Bernardo National Natural Park located in the waters of the Colombian Caribbean were analyzed. Multivariate analysis of the water quality data-set was performed through PCA. The statistical analysis showed that the nutrients are at levels close to eutrophication, the solids exceed the levels established by the regulations and the salinity presents abrupt changes in their levels, all these factors affect the health of the marine ecosystems. The principal component analysis identified four components that explain $67.27 \%$ of the total variance of the data. The first factor represents the agroindustrial contribution, the second factor represents pollution by minerals and organic matter, the third factor is due to wastewater-fertilization and the fourth factor is clearly microbiological.
\end{abstract}

Keyword - Coral systems, Environmental quality, Environmental pollution, Nutrient analysis.

\section{INTRODUCTION}

The productivity and sustainability of coastal, marine and estuarine ecosystems depend to a large extent on the quality of coastal water [1]. The regions are considered coastal areas have greater diversity than the in the open sea, however, these have been altered over time due to impacts of human activities [2]. Eutrophication and dangerous growth of algae are the biggest global problems that affect environments coastal areas, often as a result of high loads of nutrients [3].

Coral reef ecosystems support millions of dollars for the tourism and fishing industry, vital to the sustainability of local economies. But, they are threatened by the rapid growth of the population in surrounding areas, climate change and the overexploitation of the resources $[4,5]$.

Water quality in the mouth of large rivers like the Magdalena, is influenced by natural and anthropogenic factors. Temporary natural processes as rainfall, temperature changes, among others, directly affect the quality of water bodies. On the other hand, the rapid increase in the use of fertilizers and deforestation cause changes in the quality of water resources, since rivers and seas are the final destination of these pollutants [6].

Dique Canal, a ramification of the Magdalena River, transports from Calamar to Cartagena approximately $397 \mathrm{~m} 3 \cdot \mathrm{s}-1$ of water with sediments and pollutants, about $35 \%$ is discharged into barbacoas bay through matunilla and lequerica canals, $17.5 \%$ is discharged through Correa canal. Another $34 \%$ is discharged into Cartagena bay and the rest remains in muddy systems of the region [7].

From the mouth of Caño Correa, a part of the sediments is transported to the coral reefs of the Rosario and San Bernardo Islands. Many of these coral formations that persist today are in an advanced state of deterioration, or even in some areas they have already disappeared. Coral reefs, like other coastal ecosystems, are increasingly exposed to a growing load of nutrients, sediments and pollutants discharged from the continent [8]. 
As nutrients increase, reef communities change from a domain of organisms such as coral to a domain of organisms such as macro algae [9,10]. The objective of this investigation is to evaluate the state of water quality in the delta of Correa canal according to Colombian regulations and assess any possible threat to coral reef.

\section{Materials AND Methods}

Study area

The delta Caño Correa is located at coordinates 848706-1604346, to the south of Cartagena bay, in front of the Rosario and San Bernardo Islands Natural Park, as shown in Figure 1.

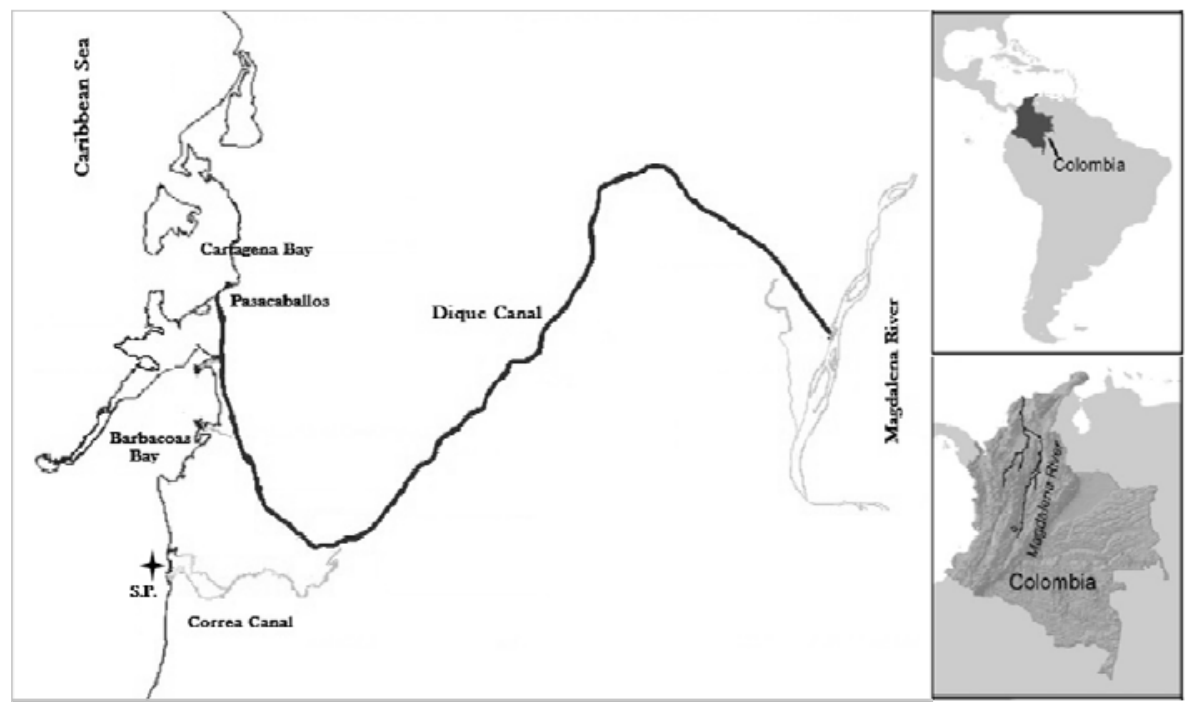

Fig 1. Sampling station in Caño Correa

In the area, two climatic periods are identified, Dry and rainy. The dry period extends from December to April, characterized by strong winds from the North - Northeast sector and weak and scarce rains; at this time, the socalled "Mares de Leva" may appear. Rainy season extends from May to November; it is characterized by weak winds, of variable orientation and by a regime of copious rains [11].

Marine water samples collection, receptacles, stabilization, and transportation to the laboratory, as well as samples storage, were done in accordance with APHA protocols. Samples were taken at $50 \mathrm{~cm} \mathrm{depth,} \mathrm{pH}$, temperature, dissolved oxygen and salinity were measured in situ. refreigerated water samples, preserved with sulfuric acid and EDTA were also taken for laboratory tests. After being taken, the samples were kept at $4^{\circ} \mathrm{C}$ in the dark and all the analyzes were done in the following 48 hours [12].

\section{Analytical methods}

The analytical methods used for the determination of the concentrations are deposited in Table 1.

Table I. Test methods

\begin{tabular}{llc}
\hline \multicolumn{1}{c}{ Parameter } & \multicolumn{1}{c}{ Method } & Standard Method \\
\hline Temperature & Termometer & SM-2550-B \\
$\mathrm{Ph}$ & Potenciométric & $\mathrm{SM}-4500-\mathrm{H}+$ \\
Dissolved oxygen & Oximeter & SM-4500-0 G \\
Salinity & Saltmeter & $\mathrm{SM}-2520-\mathrm{B}$ \\
$\mathrm{DBO}_{5}$ & Winkler & $\mathrm{SM}-4500-0 \mathrm{G}$ \\
Total suspended solids & Gravimetry & $\mathrm{SM}-2540-\mathrm{D}$ \\
Total Coliforms & Multiple tubes & $\mathrm{SM}-9222 \mathrm{~B}$ \\
Ammonium & Distillation-volumetry & SM-4500-NH3 B, C \\
Nitrate & Cadmium reduction & SM-4500-NO 3 \\
Total phosphorus & Ascorbic acid & SM-4500-P B, E \\
\hline
\end{tabular}

\section{Statistical techniques}

In order to compare the behavior of data with the law threshold values, hypothesis testing was used. Multivariate analysis of the water quality data-set was performed through PCA. Mathematical and statistical computations were made using Microsoft Office Excel and minitab 16. 


\section{Hypothesis testing}

A statistical hypothesis is a statement about the parameters of one or more populations. Hypothesis testing is an effective tool to compare the mean of a population to a specified value, in our case values of parameters to preserve flora and fauna in marine ecosystems. Hypothesis testing procedures rely on using the information in a random sample from the population of interest. If this information is consistent with the hypothesis, we will conclude that the hypothesis is true; however, if this information is inconsistent with the hypothesis, we will conclude that the hypothesis is false [13].

\section{Principal component analysis}

Principal component analysis is a multivariate analysis technique that can be used to find new variables represented by a linear combination of variables having correlations via the variance-covariance matrix of several multivariate variables; it explains most of the total variations with some important principal components [14]. The new axes lie along the directions of maximum variance. PCA provides an objective way of finding indices of this type so that the variation in the data can be accounted for as concisely as possible [15].

\section{III.RESULTS AND DISCUSSION}

\section{Initial Characterization}

Concentration of dissolved oxygen is an essential parameter to maintain equilibrium in marine ecosystems. OD for the study period presented a mean value of $5.95 \mathrm{mg} / \mathrm{L}$ and a standard deviation of $2.04 \mathrm{mg} / \mathrm{L}$, with a maximum value of $10.4 \mathrm{mg} / \mathrm{L}$ and a minimum of $1.06 \mathrm{mg} / \mathrm{L}$. Dotted line is the threshold value for OD. Values in red are outliers, which may be due to high discharges of wastewater from shrimp farms near the canal, as shown in Figure 2.

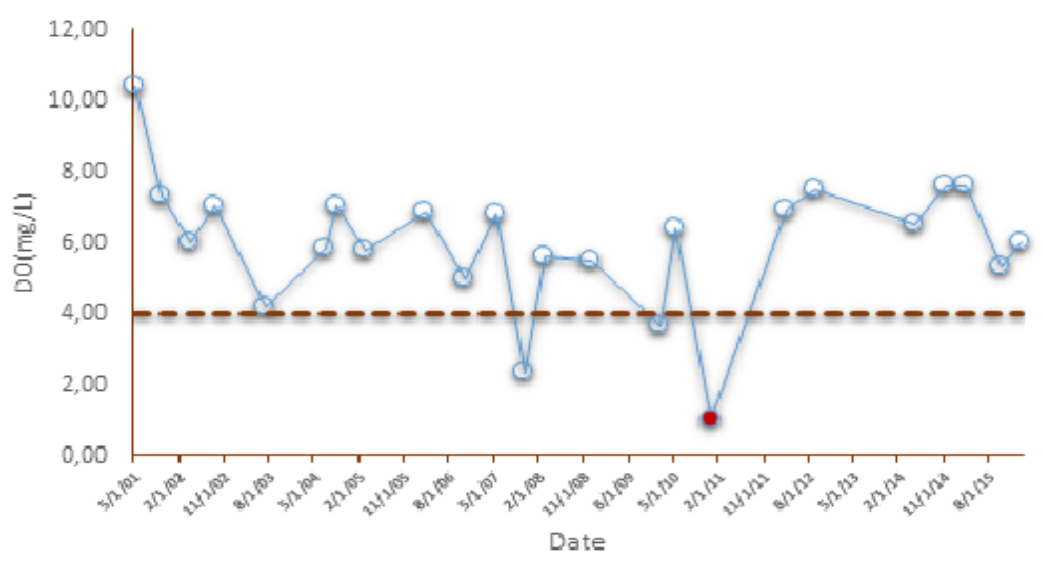

Fig 2. Dissolved Oxygen behavior in Caño Correa

In order to compare compliance with law, a hypothesis testing for the mean was performed, it showed that the mean is greater than $4 \mathrm{mg} / \mathrm{L}$ at the significance level of 0.05 as shown in Figure 3. It is $90 \%$ possible that the true mean is between $5.36 \mathrm{mg} / \mathrm{L}$ and $6.67 \mathrm{mg} / \mathrm{L}$, and a safety of $95 \%$ that is greater than $5.36 \mathrm{mg} / \mathrm{L}$. This result showed that the Colombian norm to maintain flora and fauna resources is met in the region.

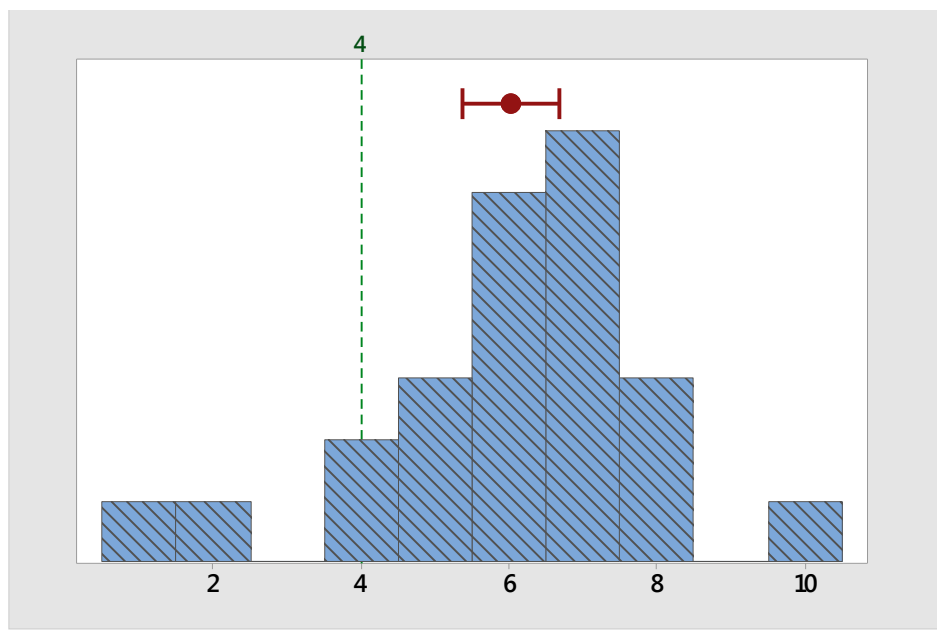

Fig 3. Hypothesis testing for dissolved oxygen 
Biochemical oxygen demand $\left(\mathrm{BOD}_{5}\right)$ is a variable that quantifies the contamination by organic matter present in water. The $\mathrm{BOD}_{5}$ presented a mean of $2.31 \mathrm{mg} / \mathrm{L}$ with a deviation of $1.69 \mathrm{mg} / \mathrm{L}$, the maximum value was 6.72 $\mathrm{mg} / \mathrm{L}$ and the minimum value of $0.38 \mathrm{mg} / \mathrm{L}$. Data above the norm (dotted line) may be caused by wastewater and agroindustrial contaminants as shown in Figure 4.

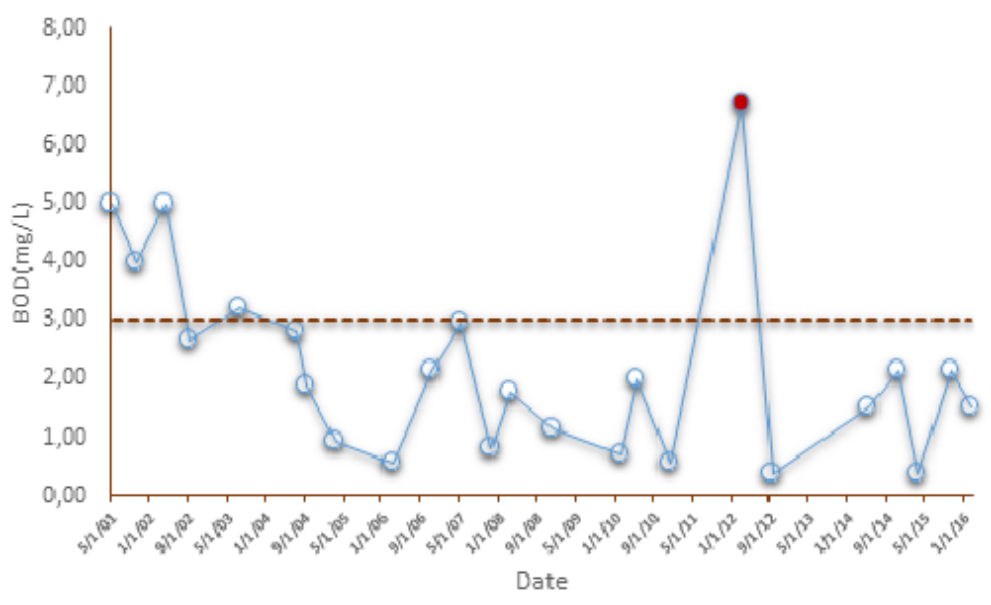

Fig 4. $\mathrm{BOD}_{5}$ time series in Caño Correa

Hypothesis testing concluded that the mean is less than $3 \mathrm{mg} / \mathrm{L}$ at the level of significance of 0.05 , which complies with Colombian regulations for the preservation of fauna and flora.

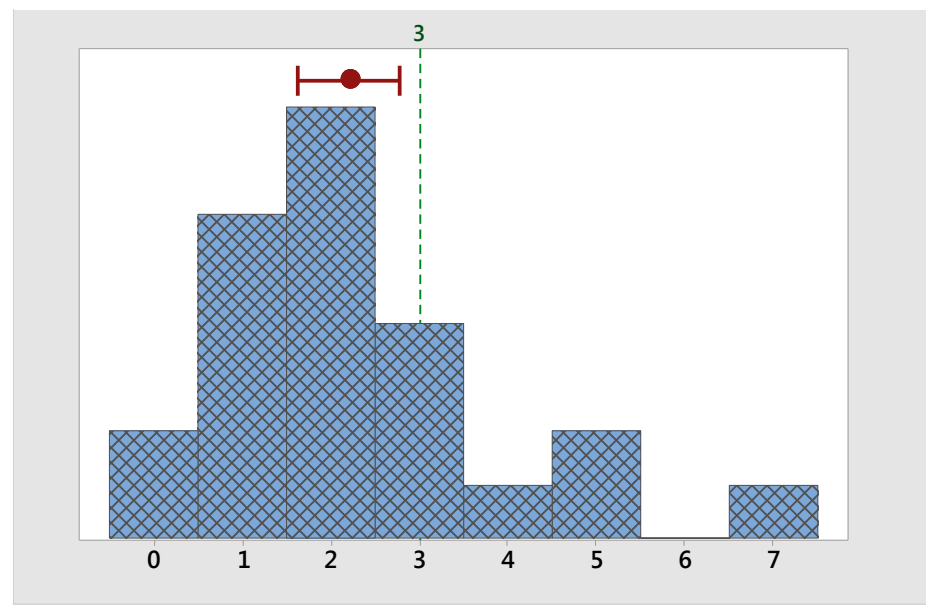

Fig 5. $\mathrm{DBO}_{5}$ Hypothesis testing

Confidence interval that quantifies the uncertainty associated with the estimation of the mean from the data of the samples, showed that $90 \%$ of the time the true mean is between $1.63 \mathrm{mg} / \mathrm{L}$ and $2.78 \mathrm{mg} / \mathrm{L}$, and with a $95 \%$ confidence is less than $2.78 \mathrm{mg} / \mathrm{L}$, which complies with the Colombian law for this parameter in water as shown in Figure 5.

$\mathrm{pH}$ in the mouth area of Correa canal showed a maximum value of 8.36 and a minimum of 5.72, with a mean of 7.67 and standard deviation of 0.75 . Low outliers values could be caused by runoff from soils fertilized with urea, which is a common practice in the area. 


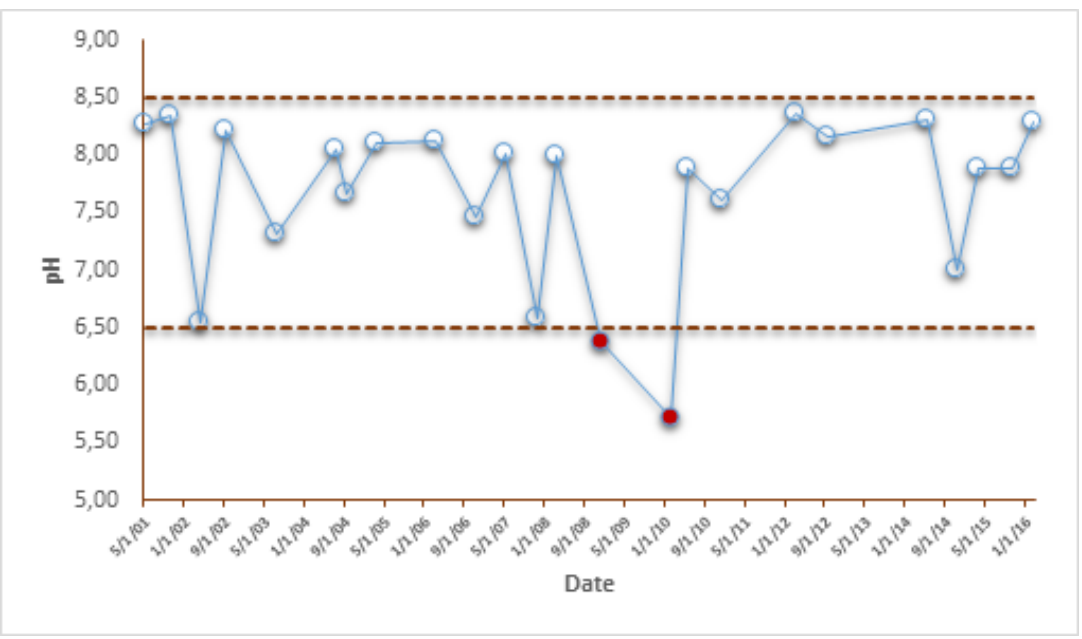

Fig 6. $\mathrm{pH}$ time series in Caño Correa

Hypothesis testing concluded that the mean is greater than 6.5 but less than 8.5 at the significance level of 0.05 . Also exists a $90 \%$ of confidence that the true mean is between 7.42 and 7.93 , and a $95 \%$ of confidence that it is greater than 7.42 and less than 8.5 as shown in Figure 6.

The main sources of coliforms in Correa canal are sewage, livestock breeding, grazing areas and the application of manure in the fields. Total coliforms analyzed by the technique of the most probable number, nine tube method, showed a mean of 1630.1 MPN with a deviation of 5238.8 MPN. The variable showed a maximum value of 24,000 MPN and a minimum value of $2 \mathrm{MPN}$.

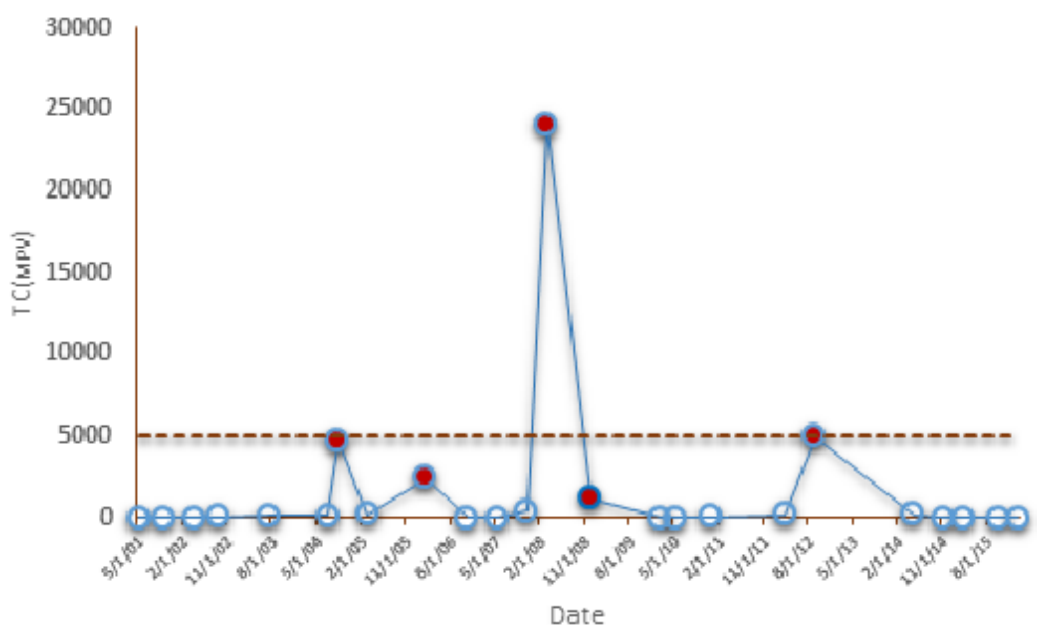

Fig 7. Total coliforms time series in Caño Correa

For coliforms hypothesis test showed that the mean is less than 5000 NMP at the significance level of 0.05 and there is a $90 \%$ confidence that the true mean is between 0 and 3357.7, and a $95 \%$ confidence that is less than 3357.7 as shown in Figure 7.

The total suspended solids reached a maximum value of $1160 \mathrm{mg} / \mathrm{L}$ and a minimum value of $5.6 \mathrm{mg} / \mathrm{L}$, the average of this variable was $110 \mathrm{mg} / \mathrm{L}$ and showed a deviation of $246.54 \mathrm{mg} / \mathrm{L}$. High values of solids may be caused by rains, either in the area of the canal or in regions of the interior of the country that increase the solids due to dragging by runoff. 


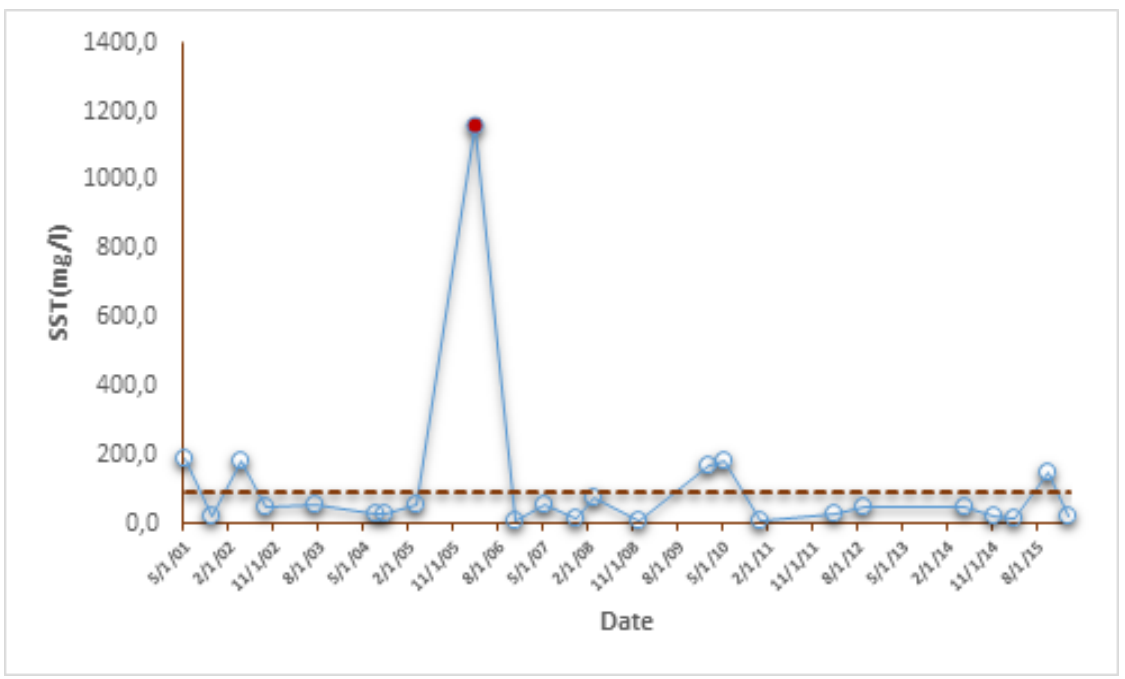

Fig 8. Total suspended solids time series in Caño Correa

In this case hypothesis testing showed that there is not enough evidence to conclude that the mean is less than 90 $\mathrm{mg} / \mathrm{L}$ at the significance level of 0.05 . The true mean is between $27.22 \mathrm{mg} / \mathrm{L}$ and $189.61 \mathrm{mg} / \mathrm{L}$, and exists a $95 \%$ confidence that it is less than $189.61 \mathrm{mg} / \mathrm{L}$. It may be statistically concluded, that this parameter is not within the ranges established by law as shown in Figure 8 .

Ammonium is a water-soluble gas that appears in low concentrations in natural waters. It usually comes from organic material with nitrogen content and from gas exchange between water and the atmosphere. In Correa canal, ammonium behaved in accordance with the law, obtaining values below $1 \mathrm{mg} / \mathrm{L}$ as estipulated in the Colombian regulations, the mean of this variable was $0.26 \mathrm{mg} / \mathrm{L}$ and showed a deviation of $0.26 \mathrm{mg} / \mathrm{L}$, its maximum value was $0.8 \mathrm{mg} / \mathrm{L}$ and the minimum value was $0.07 \mathrm{mg} / \mathrm{L}$ as shown in Figure 9 .

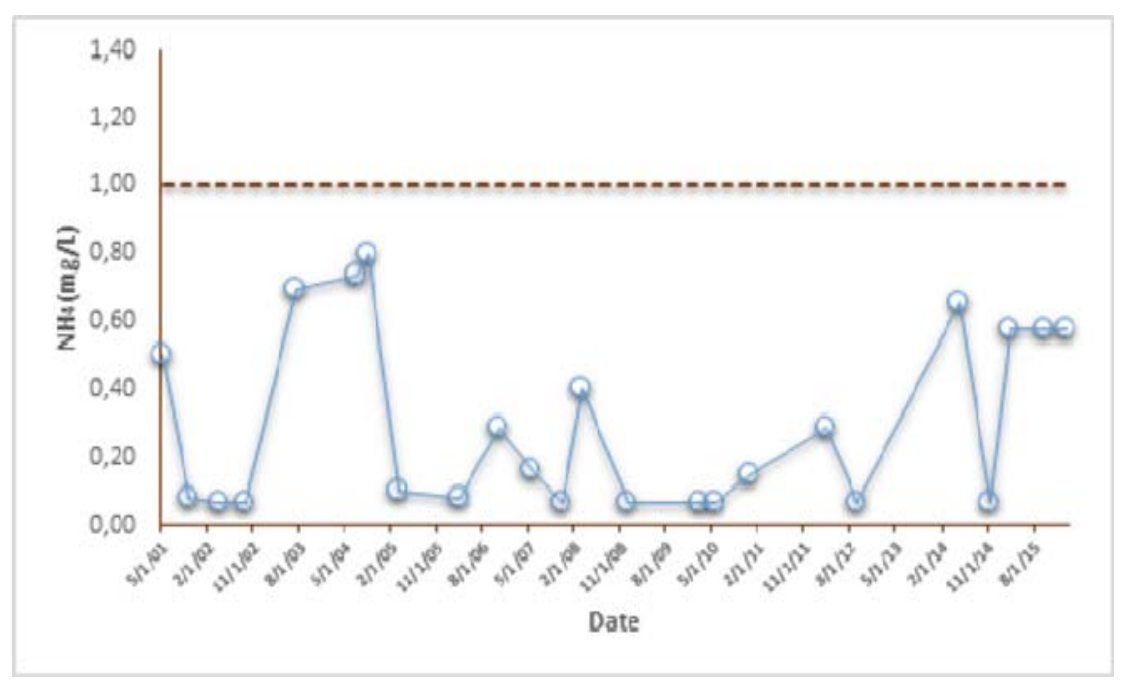

Fig 9. Ammonium time series in Caño Correa

Nitrates are in nature in concentrations of 1-10 ppm. A high concentration of this chemical degradates the fauna and flora of water bodies. In this study, the nitrates parameter $\left(\mathrm{NO}_{3}{ }^{-}\right)$showed a maximum value of 1.01 and a minimum of $0.012 \mathrm{mg} / \mathrm{L}$. The average presented was $0.104 \mathrm{mg} / \mathrm{L}$ and the standard deviation was $0.23 \mathrm{mg} / \mathrm{L}$. 


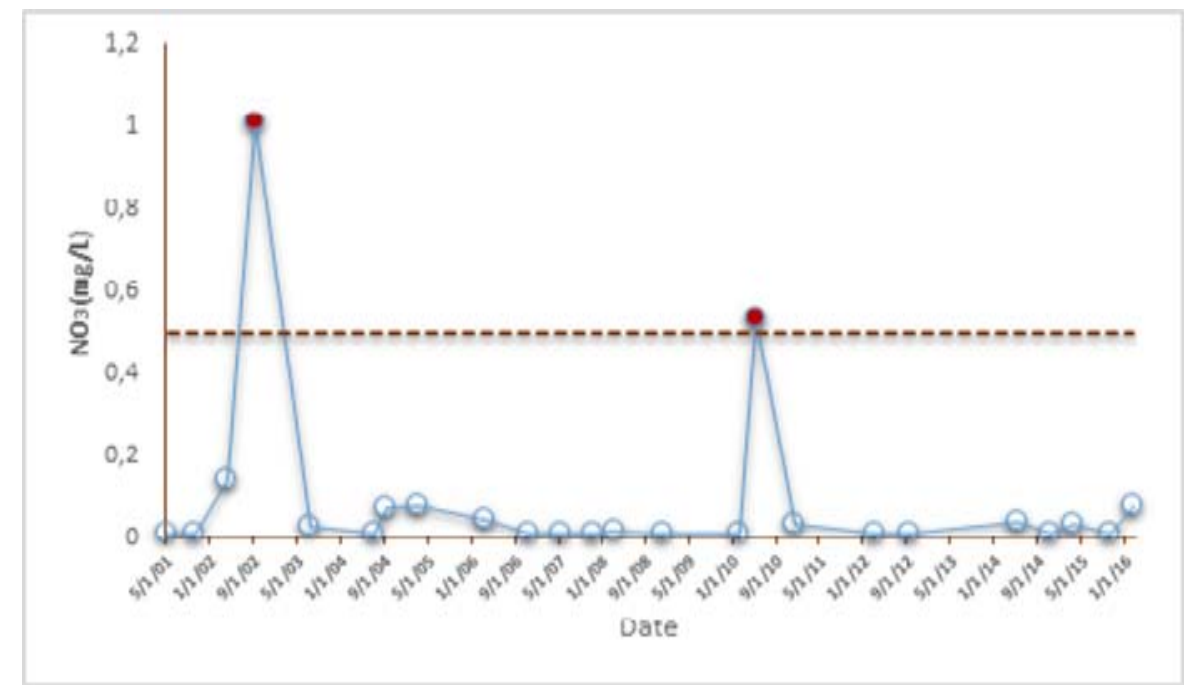

Fig 10. Nitrates time series in Caño Correa

Hypothesis testing showed that the mean is less than $0.5 \mathrm{mg} / \mathrm{L}$ at the significance level of 0.05 . The confidence interval for the variable was $0.017 \mathrm{mg} / \mathrm{L}-0.177 \mathrm{mg} / \mathrm{L}$, and a there was a $95 \%$ confidence that it was less than $0.172 \mathrm{mg} / \mathrm{L}$. Runoff and leaching processes might affect the concentration of this analyte, which caused the appearance of outliers on data as shown in Figure 10.

Total phosphorus includes organic and inorganic phosphorus, the discharge of residual domestic waters and drainage of fertilized lands contribute to the increase in their concentration. Total phosphorus showed a mean value of $0.12 \mathrm{mg} / \mathrm{L}$ and a standard deviation of $0.10 \mathrm{mg} / \mathrm{L}$, its maximum value was $0.49 \mathrm{mg} / \mathrm{L}$ and the minimum value was $0.031 \mathrm{mg} / \mathrm{L}$.

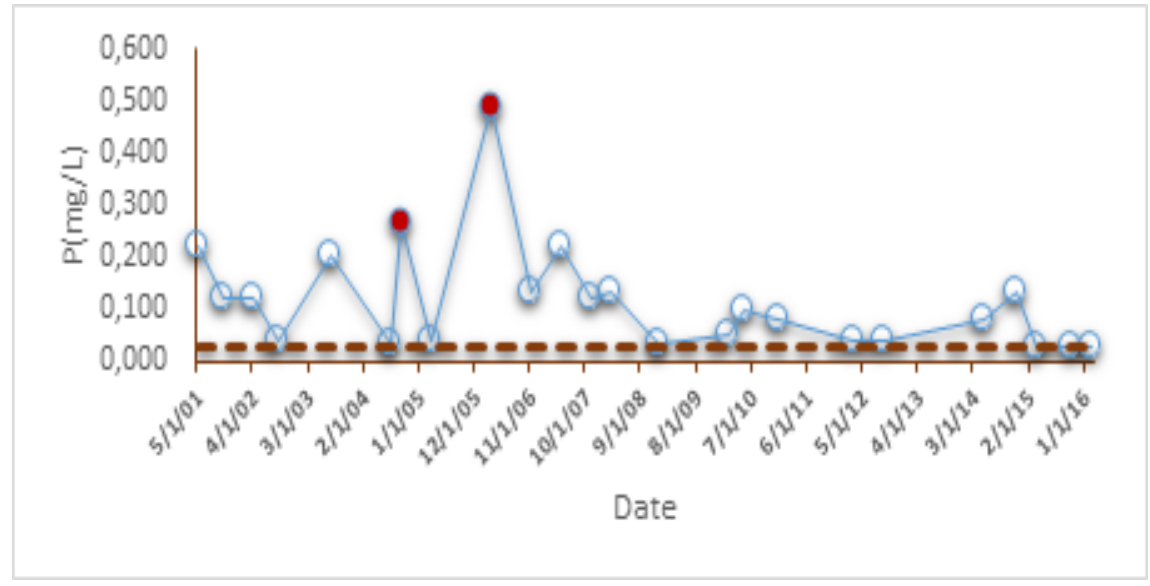

Fig 11. Total phosphorus in Caño Correa

According to the hypothesis testing there is not enough evidence to conclude that the mean is less than 0.03 $\mathrm{mg} / \mathrm{L}$ at the significance level of 0.05 . With a $90 \%$ confidence, the true mean is between $0.078 \mathrm{mg} / \mathrm{L}$ and 0.153 $\mathrm{mg} / \mathrm{L}$, and it is less than $0.153 \mathrm{mg} / \mathrm{L}$. This means that phosphorus is out of the range recommended by authors for the preservation of flora and fauna and it is near to eutrophication levels of water as shown in Figure 11.

Salinity showed a maximum value of 37 NTU and a minimum value of 0.0 NTU, with an average of 19.19 NTU and a standard deviation of 14.35 NTU. 


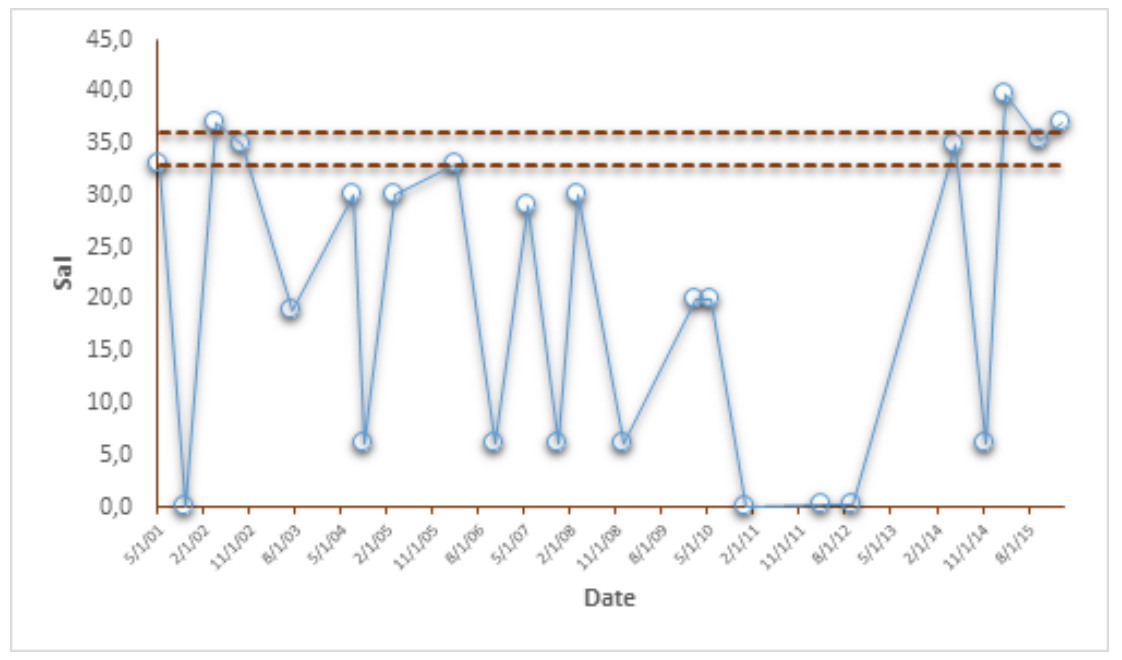

Fig 12. Salinity time series in Caño Correa

There is not enough evidence to conclude that the mean is greater than $32 \mathrm{NTU}$ at the significance level of 0.05 . The true mean is between 15,43 NTU and 25,69 NTU, and exists a confidence of $95 \%$ that it is greater than 15,43 NTU. The standard for salinity is not achieved in Correa canal, probably this is due to the high flow of fresh water entering the delta of the canal, especially in rainy season as shown in Figure 12.

\section{Multivariate Statistical Analysis}

PCA based on the correlation matrix was performed to understand the underlying relationships between the water quality variables to identify their characteristics. Principal Components loadings were classified as 'strong', 'moderate', and 'weak' according to absolute loading values of $>0.75,0.75-0.50$ and $0.50-0.30$, respectively. The scree plot as shown in Figure 13, was used to identify the number of PCs in the database. This Figure shows a pronounced change of slope after the 4th eigenvalue, so four components were retained, which have eigenvalues greater than unity and explain $67.267 \%$ of the information contained in the data set.

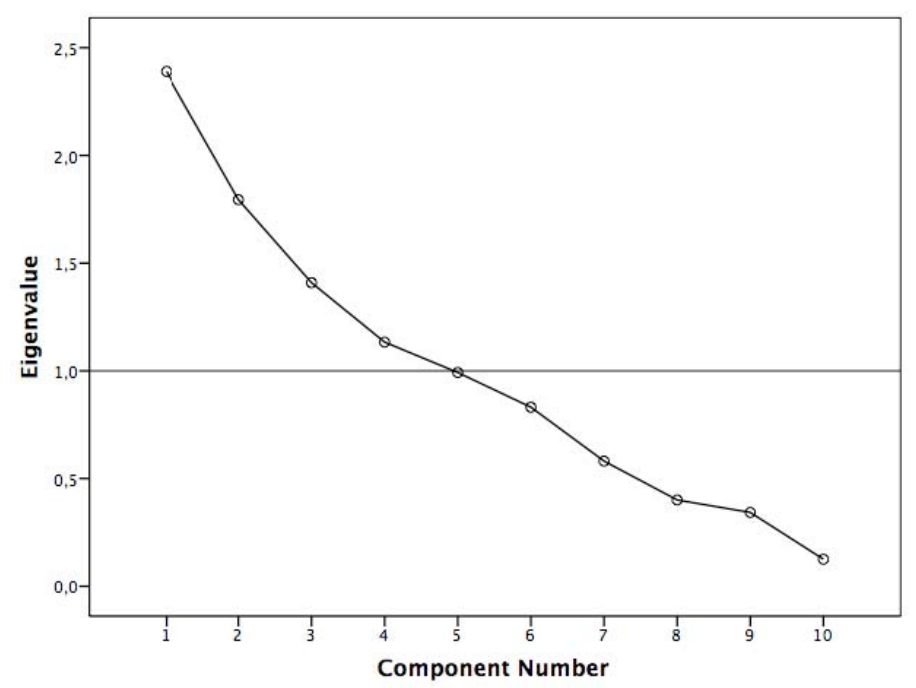

Fig 13. Scree plot

Loading of four retained PCs are presented in Table 2. PC1 explains $23.90 \%$ of the variance and is highly contributed to by $\mathrm{P}, \mathrm{DO}, \mathrm{pH}$ and Sal. These factors mainly represent the contribution of different pollution sources like agroindustrial effluent, domestic wastewater, and were influenced by seasonal conditions like salinity. 
Table II. Loadings of experimental parameters

\begin{tabular}{lcccc}
\hline & \multicolumn{4}{c}{ Component } \\
\hline Variables & $\mathbf{1}$ & $\mathbf{2}$ & $\mathbf{3}$ & $\mathbf{4}$ \\
\hline $\mathrm{NH}_{4}$ & 0.325 & 0.286 & 0.671 & 0.127 \\
$\mathrm{BOD}$ & 0.385 & 0.645 & 0.011 & -0.369 \\
$\mathrm{P}$ & 0.604 & -0.636 & 0.194 & -0.238 \\
$\mathrm{NO}_{3}$ & 0.165 & 0.192 & -0.765 & 0.444 \\
$\mathrm{DO}$ & 0.751 & 0.342 & -0.076 & -0.138 \\
$\mathrm{pH}$ & 0.632 & 0.306 & 0.108 & 0.289 \\
$\mathrm{~T}$ & 0.300 & 0.208 & -0.116 & -0.341 \\
$\mathrm{TSS}$ & 0.548 & -0.754 & -0.167 & -0.159 \\
$\mathrm{Sal}$ & 0.609 & -0.109 & -0.267 & 0.318 \\
$\mathrm{TC}$ & 0.142 & -0.146 & 0.455 & 0.619 \\
Eigenvalue & 2.390 & 1.794 & 1.409 & 1.133 \\
$\%$ of variance & 23.899 & 17.945 & 14.091 & 11.333 \\
Cumulative & 23.899 & 41.844 & 55.935 & 67.267 \\
\hline
\end{tabular}

PC2, explains $17.95 \%$ of the variance, has strong positive loading on BOD and has strong negative loading on phosphorus and total solids; this factor represents the mineral and organic pollution and ascribes to the runoff from phosphorous fertilizers, soil erosion and waste water. PC3 explains $14.09 \%$ of variance is contributed to by $\mathrm{NH}_{4}{ }^{+}$and negatively contributed to by $\mathrm{NO}_{3}{ }^{-}$. This factor may be attributed to biogenic and anthropogenic (wastewater) pollution sources. $\mathrm{NO}_{3}^{-}$may additionally derive from agricultural areas in the region where inorganic nitrogen fertilizers are in common use. PC4 is highly contributed to by coliforms, this factor represents essentially the bacteriological pollution originated from the domestic waste and leaching from agricultural land using animal humus (Agricultural drainage) and explains $11.33 \%$ of the variance.

\section{Corals}

Coral reefs have a high economic value as they provide coastal protection, supply food and natural products, and attract tourists from all over the world. These highly productive and biodiverse ecosystems also provide hundreds of species for the marine aquarium hobbyists. Corals are among the most lucrative organisms in this trade and their demand has been increasing steadily [16].

The presence of humans in the proximity of coral reefs usually results in an elevated input of nutrients into reef waters. Nutrients associated with human activities, are introduced in various forms: they reach the marine environment as organic and inorganic compounds, they may be dissolved in the water or contained in sediments or in particulate organic matter and might enter reef ecosystems. Consequently, the decline of coral reefs close to urbanized areas or to agriculturally or industrially exploited regions has been considered to be promoted by anthropogenic nutrient enrichment of reef waters [17].

Studies had shown that nutrient enrichment has a negative effect on coral reproduction, and its calcification, decreasing the growth rate of the reef [18]. This may bring to algal overgrowth of the reef, with a phase shift coral/macroalgae. Nutrient enrichment is also correlated with a major incidence in coral diseases [19]. To avoid nutrient enrichment on coral reefs, the biologically available nitrogen (nitrates and ammonia) should be lower than $1.0 \mathrm{uM}(<0.014 \mathrm{ppm})$, and the biologically available phosphorous less than $0.1 \mathrm{uM}(<0.003 \mathrm{ppm})$ [20].

High sediments and low salinity have inhibitory effects on reef communities and the sedimentary processes, including various associations between substrate type, turbidity and light availability, affect coral distributions on all scales from local depth restrictions to broad-scale biogeography [21].

Caño Correa concentration of solids, nutrients and salinity have contributed to current low levels (22\%) of coral cover in Rosario Island and San Bernado Natural Park [22]. This might be attributed to many stressors, including freshwater-induced bleaching due to low salinity; sediment and nutrient loading enhancing the ability of macro algae to compete with corals for benthic substrate and increased anthropogenic contamination from urban and rural areas. 


\section{IV.CONCLUSIONS}

Hypothesis testing applied to the information from the delta of Caño Correa showed that phosphorus, salinity and solids variables were outside of what is established in the Colombian regulations for the preservation of the flora and fauna of the marine ecosystems. Solids and salinity behavior might be caused by temporal natural phenomena, while anthropogenic effects govern phosphorus levels, such as the dumping of agro-industrial waters and the use of fertilizers. Nitrogen levels, although within the parameters, maintained a high-level due to the fertilization of soils in an erroneous way by nearby communities.

\section{REFERENCES}

[1] A. Adepelumi, B. Ako, T. Ajayi, O. Afolabi, E. Omotoso, "Delineation of saltwater intrusion into the freshwater aquifer of Lekki Peninsula, Lagos, Nigeria," Environ. Geol., vol. 56, pp. 927-933, 2009.

[2] R. Acevedo, C. Severiche, J. Jaimes, "Bacterias resistentes a antibióticos en ecosistemas acuáticos," Revista Producción Mas Limpia., vol.15, no.2, pp. 160-172, 2015.

[3] C. Severiche, I. Baldiris, J. Acosta, E. Bedoya, I. Castro, H. Pacheco. "Multivariate Analysis of Water Quality in Rosario Islands National Park (Colombia), " American Journal of Engineering Research., vol. 6, no.6, pp.136 - 144, 2017.

[4] Wesli, "Analysis Water Balance of Lake Toba as Source an Integrated Water Regional Management (IWRM) North Sumatera," International Journal of Engineering and Technology., vol. 9, no. 5, 3945-3953, 2017.

[5] R. Acevedo, C. Severiche, "Identificación de Bacterias Resistentes a Di-Bromo- Mercurio Aisladas de Sedimentos en Playas de Cartagena de Indias, Caribe Colombiano," Revista Avances Investigación en Ingeniería., vol.10, no.2, pp. 73 - 79, 2013.

[6] M. Hajigholizadeh, A. Melesse, "Assortment and spatiotemporal analysis of surface water quality using cluster and discriminant analyses," Catena., vol. 151, pp. 247-258, 2017.

[7] M. Moreno, D. Rickman, I. Ogashawara, D. Irwin, J. Ye, M. Al-Hamdan, "Using remote sensing to monitor the influence of river discharge on watershed outlets and adjacent coral Reefs: Magdalena River and Rosario Islands, Colombia," International Journal of Applied Earth Observation and Geoinformation., vol. 38, pp. 204-215, 2015.

[8] J. Restrepo, J. Ortiz, J. Pierini, K. Schrottke, M. Maza, L. Otero, J. Aguirre, "Freshwater discharge into the Caribbean Sea from the rivers of Northwestern South America (Colombia ): Magnitude, variability and recent changes," Journal of Hydrology., vol. 509, pp. 266-281, 2014

[9] W. Maldonado, I. Baldiris, J. Díaz, "Evaluación de la calidad del agua en la Ciénaga de la Virgen (Cartagena, Colombia) durante el período 2006-2010," Revista Científica Guillermo de Ockham., vol. 9, no. 2, pp. 79-87, 2011.

[10] C. Severiche, A. Barreto, R. Acevedo, "Efecto De Las Lluvias Sobre La Calidad Del Agua En La Ciénaga Grande De Santa Marta, Colombia," Revista Avances Investigación en Ingeniería., vol.10, no.1, pp. 58 - 67, 2013.

[11] J. Acosta, I. Baldiris, H. Pacheco, "Analisis de la variacion de la calidad del agua en la bahia de Barbacoas-Cartagena durante el periodo 2001-2014,” Revista Ingeniería e Innovación., vol. 3, no. 1, pp. 7-17, 2015.

[12] C. Severiche, M. Castillo, and R. Acevedo. Manual de Métodos Analíticos para la Determinación de Parámetros Fisicoquímicos Básicos en Aguas. Editado por la Fundación Universitaria Andaluza Inca Garcilaso para eumed.net. 1 Ed. Malaga (España), 2013. www.eumed.net/libros-gratis/2013a/1326/1326.pdf

[13] W. Fong, L. Vargas, C. Severiche, E. Espinosa and Y. Marrugo, "Multivariate analysis on the influence of physicochemical parameters on the calorific value of oils used in the petrochemical industry," International Journal of Engineering and Technology., vol. 9, no. 4, pp. 3355-3360, 2017.

[14] S. Rosmin, M. Ennis, K. Brandt, G. Wilson, S. Tyler, "Coral reef health response to chronic and acute changes in water quality in St. Thomas, United States Virgin Islands,” Marine Pollution Bulletin., vol. 111, no. 1-2, pp. 418-427, 2016.

[15] K. Jung, K. Lee, T. Im, I. Lee, S. Kim, K. Han, J. Ahn, "Evaluation of water quality for the Nakdong River watershed using multivariate analysis," Environmental Technology \& Innovation., vol. 5, pp. 67-82, 2016.

[16] C. Sheridan, E. Kramarsky, M. Sweet, A. Kushmaro, M. Leal, "Diseases in coral aquaculture: Causes, implications and preventions," Aquaculture., vol. 396-399, pp. 124-135, 2013.

[17] C. D'Angelo, J. Wiedenmann, "Impacts of nutrient enrichment on coral reefs: New perspectives and implications for coastal management and reef survival," Current Opinion in Environmental Sustainability, vol. 7, no. 2, 82-93, 2014.

[18] M. Rocker, D.Francis, K. Fabricius, B. Willis, L. Bay. "Variation in the health and biochemical condition of the coral Acropora tenuis along two water quality gradients on the Great Barrier Reef, Australia," Marine Pollution Bulletin., vol. 119, no. 2, pp.106-119, 2017.

[19] B. Gavio, S. Palmer, J. Mancera, "Historical analysis (2000-2005) of the coastal water quality in San Andres Island, SeaFlower Biosphere Reserve, Caribbean Colombia," Marine Pollution Bulletin., vol. 60, no. 7, pp. 1018-1030, 2010.

[20] M. Roberts, N. Hanley, S. Williams, W. Cresswell. "Terrestrial degradation impacts on coral reef health: Evidence from the Caribbean," Ocean \& Coastal Management., vol. 149, pp.52-68, 2017.

[21] J. Restrepo, P. Zapata, J. Diaz, J. Garzon, C. Garcia, "Fluvial fluxes into the Caribbean Sea and their impact on coastal ecosystems : The Magdalena River, Colombia," Global and Planetary Change., vol. 50, pp. 33-49, 2006.

[22] E. Alvarado, A. Acosta, "Population size-structure of the reef-coral Montastraea annularis in two contrasting reefs of a marine protected area in the southern Caribbean Sea," Bulletin of Marine Science., vol. 85, no. 1, pp. 61-76, 2009. 